\title{
Ayurvedic Management of Infertility W.S.R. Anovulation: A Case Study
}

\author{
${ }^{* 1}$ Neha Pandya, ${ }^{2}$ Hetal P. Baraiya
}

${ }^{1}$ Prof. \& HOD, Dept. of Prasootitantra \& Streeroga, Shri G. A. College, Gujarat Ayurved University, Jamnagar

${ }^{2}$ Associate Professor, Dept. of Prasootitantra \& Streeroga, Shri G. A. College, Gujarat Ayurved University, Jamnagar

\begin{abstract}
Patient was anxious to conceive after active married life of 5 years. The present case study was done to evaluate the role of Ayurvedic Shodhana therapy i.e. Yogabasti for two consecutive menstrual cycles in the management of anovulation. After completing two courses of Yogabasti, improvement was noticed i.e. Ovulation study (during treatment - anovulatory cycle, After treatment - ovulatory cycle). The line of treatment was followed in this case was to treat the provoked Vata Dosha and vitiated Rasa Dhatu. There were no adverse effects found during the Ayurvedic Panchakarma procedure i.e. Yogabasti.
\end{abstract}

Keywords: Anovulation, Panchakarma, Shodhana, Yogabasti

Article Info: Received 04 July 2019; Review Completed 12 Aug 2019; Accepted 28 Aug 2019; Available online 15 Oct 2019

Cite this article as:

Pandya N, Baraiya HP, Ayurvedic Management of Infertility W.S.R. Anovulation: A Case Study, Journal of Drug Delivery and Therapeutics. 2019; 9(5-s):151-153 http://dx.doi.org/10.22270/jddt.v9i5-s.3626

*Address for Correspondence:

Vd. Neha Pandya, Professor \& HOD, Dept. of Prasootitantra \& Streeroga, Shri G. A. College, G. A. U., Jamnagar-361008, India.

\section{Introduction}

Infertility is commonly increasing problem which any gynaecologist has to face in their gynaecological career. It affects the mental and physical health of a woman and disturbs her family as well as social life. Ovulation disorders appear to be the most common cause of infertility in women. Due to this H-P-O axis is disturbed and menstrual cycle becomes anovulatory.[1] In Ayurved infertility is explained as Vandhyatva. The main causative factor for Vandhyatva is Vata Dosha and it is also mentioned in Rasa Dhatu Pradoshaja Vikara. So according to Ayurvedic perspective the line of treating is to treat provoked Vata Dosha and vitiated Rasa Dhatu.

\section{Case history}

A female subject, aged 30 years, housewife, living in Jamnagar, Gujarat, wants to conceive. After 5 years of married life, she was unable to conceive. Ultrasonography suggested no any abnormality in uterus and adnexa but anovulatary cycle. HSG (hysterosalpingography) suggested bilateral fallopian tubal patency. The semen analysis of the partner was normal. She had gone through 3 years of allopathic treatment but she did not get any relief. Therefore, she consulted for Ayurvedic medication. She had no previous medical or surgical illness. On examination, it was found that she was belonging to Vatapittaj Prakriti and there was no abnormal finding seen in general and systemic examination. Menstrual history was 4 to 5 day per 30 to 35 days, regular, moderate, painless before treatment. Micturation history was 5 to 6 time per day. Bowel history was 1 time per day. During per speculum examination, no abnormality found. During per vaginal examination, Anteflex Anteverted uterus and no tenderness in cervix. BP was $110 / 76 \mathrm{mmHg}$, pulse was76/min, weight was $56 \mathrm{~kg}$ and height was $154 \mathrm{~cm}$.

\section{Treatment protocol}

Following treatment was carried out (Table 1) upto months. During this period she was advised to take Laghu, Supachya Aahara (which is easy to digest) and to avoid Divaswapna (sleeping at day time).

\section{Table 1: Medication}

\begin{tabular}{|l|l|}
\hline \multicolumn{2}{|c|}{$\begin{array}{l}\text { Yogabasti for two consecutive menstrual cycles after } \\
\text { menstruation }\end{array}$} \\
\hline Anuvasana Basti: & Asthapana Basti: \\
Sahachara Taila- $100 \mathrm{ml}$ & Dashmula Kwatha $-250 \mathrm{ml}$ \\
& Sahachara Taila- $100 \mathrm{ml}$ \\
& Shatapushpa Kalka- $50 \mathrm{gm}$ \\
& Madhu $-30 \mathrm{gm}$ \\
& Saindhava $-5 \mathrm{gm}$ \\
\hline
\end{tabular}




\section{Observation and result}

Within three months of medication ovulation occurred.

Table 2: Investigations

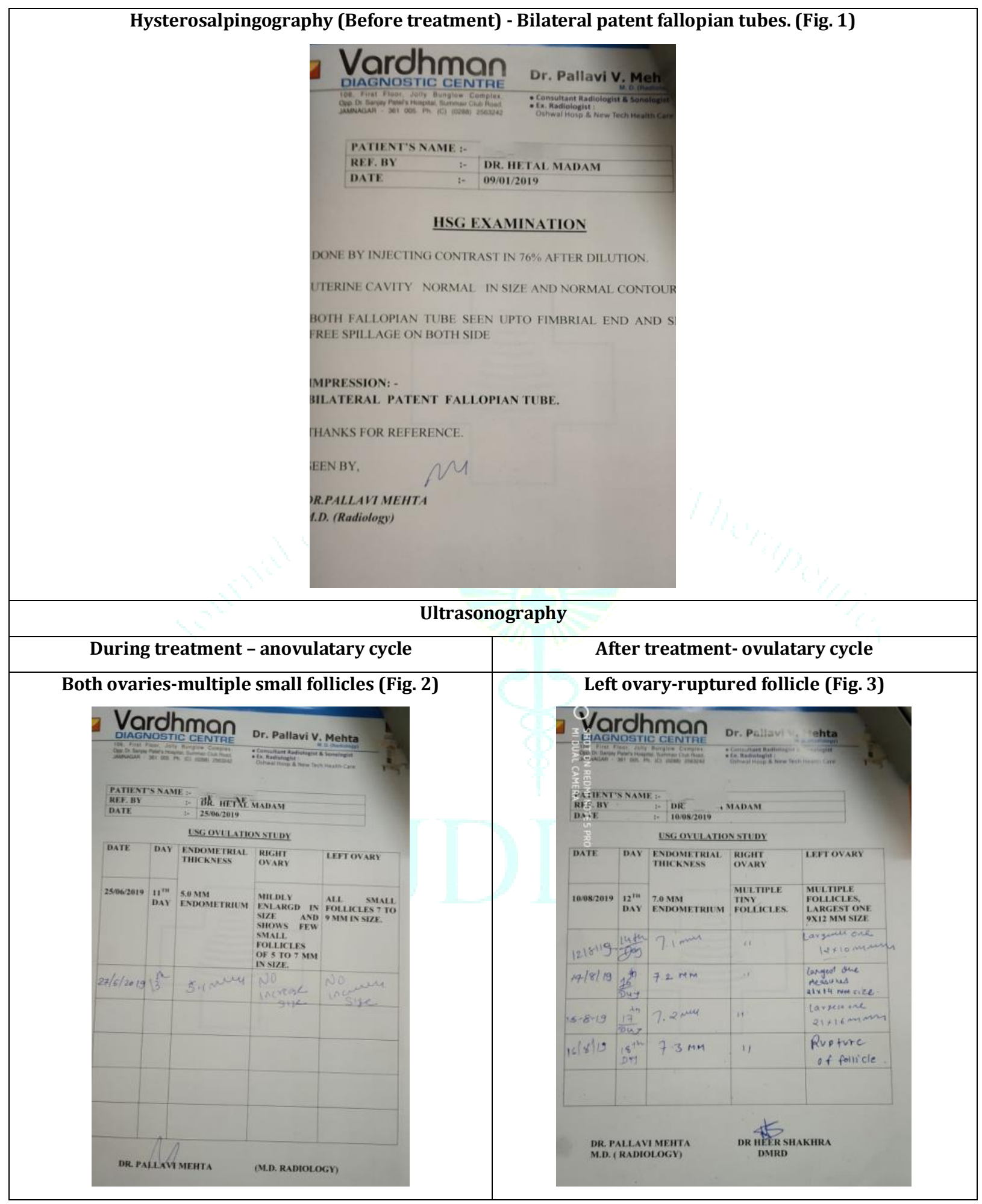

\section{Discussion}

Vandhyatva due to ovarian factor is Vata-Kapha Pradhana Vyadhi. It is Vikruti of Vata Dosha i.e. Apana Vayu Karmatah Hani occurs. Hence main line of treatment could be Vata Kapha Shamaka, Agnidipana, Pachaka and Vatanulomaka and Brimhana. Impairment of Apana Vayu is primarily responsible for this trouble. Its normal course is downwards and if it does not move because of hormonal imbalance, constipation or any other factor. Basti is the best Panchakarma procedure for Vataroga as per Ayurvedic classics. [2] Yogabasti [3] with Dashmula Kwatha was used as Niruha Basti because Dashmula has been proved Uttama Vatagna and Sahachara Taila is also best Shamana Dravya for Vata[4]. Shatapushpa Kalka is best drug Dravya for Vandhyatva i.e. infertility.[5], [6] Probably these all clear pathogenesis of anovulation. 


\section{Conclusion}

Thus present case study concludes that the holistic approach of Ayurvedic system of medicine gives relief to the patient of infertility which is caused due to ovarian factor. Yogabasti causes de-toxification of the body, removes Sroto Sanga, pacifies Tridosha especially Vata. It stimulates the H-P-O axis with promoting ovulation. There were no adverse effects found during this Ayurvedic medication.

\section{References}

[1] D.C. Dutta's, Textbook of Gynecology, $6^{\text {th }}$ edition, published by New Central Book Agency (P) ltd., Kolakata, pg. 444, 445
[2] https://www.banyanbotanicals.com/info/blog-banyanvine/details/basti-the-primary-treatment-for-vata, cited $30^{\text {th }}$ July, 2019.

[3] Thorwe Preeti et.al., Effect of Yogabasti Upakrama in Case of Infertility due to PCOS: Single Case Study Report, ma, Int. J. Ayu. Alt. Med., 2014; 2(6):45-48

[4] Thorwe Preeti et.al., Effect of Yogabasti Upakrama in Case of Infertility due to PCOS: Single Case Study Report, ma, Int. J. Ayu. Alt. Med., 2014; 2(6):45-48

[5] Bhavaprakasa Nighantu of Sri Bhava Misra by Sri Brahmasankara Misra, First Part published by Chaukhambha Sanskrit Sansthan; Varanasi, 11 $1^{\text {th }}$ edition-2007, Haritakyadi Varga 89-92; pg 35.

[6] Lavekar GS. et al. Database on Medicinal Plants Used in Ayurveda, Vol. 8. Central Council for Research in Ayurveda \& Siddha, New Delhi, India, 2007: pg.349. 